\title{
APLIKASI KAMUS ELEKTRONIK BAHASA ISYARAT BAGI TUNARUNGU DALAM BAHASA INDONESIA BERBASIS WEB
}

\author{
Yuli Fauziah, Bambang Yuwono, Cornelius D.W.P. \\ Jurusan Teknik Informatika UPN "Veteran" Yogyakarta \\ Jl. Babarsari 2 Tambakbayan 55281 Telp (0274) 485323 \\ e-mail : yuli.if@gmail.com , bambangy@gmail.com
}

\begin{abstract}
Communication is the key to conquering this globalization era. And there is no doubt that the language is the most important part of communication. One can communicate well when using the same language or understanding the language used to each other.Sign language is the language of communication priority manually, body language and lip motion in communicating. Sign language has been standardized by the name Sibi (Cue System Indonesian). Sibi is one of the media in the form of books, can help communication among the deaf in the community. His form is setting a systematic set of fingers, hands, and other movements that symbolize Indonesian vocabulary. Media book seems less easily understood by the user, so the need for an application that is able to provide an image that is moving, making it easier to learn the sign language.
\end{abstract}

\section{Keywords: Communication, Systems cues Indonesian language, Sign Language}

Komunikasi merupakan kunci utama untuk menaklukkan era globalisasi ini. Dan tidak dapat dipungkiri bahwa bahasa adalah bagian terpenting dari komunikasi. Seseorang dapat berkomunikasi dengan baik apabila menggunakan bahasa yang sama atau saling memahami bahasa yang digunakan satu sama lain. Bahasa isyarat merupakan bahasa yang mengutamakan komunikasi manual yaitu bahasa tubuh, dan gerak bibir dalam berkomunikasi. Bahasa isyarat ini telah dibakukan dengan nama SIBI (Sistem Isyarat Bahasa Indonesia). SIBI merupakan salah satu media yang berbentuk buku, mampu membantu komunikasi sesama kaum tunarungu di dalam masyarakat. Wujudnya adalah tataan yang sistematis tentang seperangkat jari, tangan, dan berbagai gerakan yang melambangkan kosa kata bahasa Indonesia. Media buku agaknya kurang dapat dipahami dengan mudah oleh pemakainya, sehingga perlu adanya suatu aplikasi yang mampu memberikan suatu gambar yang bersifat bergerak, sehingga mempermudah dalam mempelajari bahasa isyarat tersebut.

Kata Kunci : Komunikasi, Sistem Isyarat bahasa Indonesia, Bahasa Isyarat

\section{PENDAHULUAN}

Manusia adalah makhluk sosial, yaitu makhluk yang tidak dapat hidup sendiri karena membutuhkan orang lain dalam kehidupannya. Dalam melaksanakan fungsinya sebagai makhluk sosial, manusia dituntut memiliki berbagai ketrampilan, salah satunya adalah ketrampilan berkomunikasi, baik secara verbal maupun non verbal. Untuk dapat berkomunikasi, manusia menggunakan bahasa sebagai alat komunikasinya. Melalui bahasa, manusia bisa bersosialisasi dengan lingkungannya, melakukan interaksi antara yang satu dengan yang lainnya, dan segala aktivitas dalam masyarakat selalu melibatkan bahasa.

Pada umumnya, berkomunikasi dengan berbicara dianggap sebagai ciri khas manusia makhluk sosial. Kaum tunarungu, karena tidak dapat menggunakan indera pendengarannya secara penuh, sulit untuk mengembangkan kemampuan berbicara, sehingga hal tersebut akan menghambat perkembangan kepribadian, kecerdasan, dan penampilannya sebagai makluk sosial. Untuk itu kaum tunarungu memerlukan bahasa khusus dalam berkomunikasi.

Bahasa isyarat ini telah dibakukan dengan nama SIBI (Sistem Isyarat Bahasa Indonesia). SIBI merupakan salah satu media yang berbentuk buku, mampu membantu komunikasi sesama kaum tunarungu di dalam masyarakat. Wujudnya adalah tataan yang sistematis tentang seperangkat jari, tangan, dan berbagai gerakan yang melambangkan kosa kata bahasa Indonesia. Media buku agaknya kurang dapat dipahami dengan mudah oleh 
pemakainya, sehingga perlu adanya suatu aplikasi yang mampu memberikan suatu gambar yang bersifat bergerak, sehingga mempermudah dalam mempelajari bahasa isyarat tersebut.

Batasan masalah pada pembuatan aplikasi ini adalah:

1. Sistem hanya mampu menterjemahkan kata yang dicari ke bentuk video peragaan isyarat (berupa gerakan tangan sesuai dengan kata yang dicari).

2. Di dalam $S I B I$, kata yang diawali huruf $Q$ dan $X$ tidak ada isyaratnya.

3. Kata isyarat yang digunakan masih sangat terbatas yaitu 170 kata, terdiri dari kata benda, kata kerja, kata sifat, kata tanya, kata sambung, kata dasar, dan kata berimbuhan.

4. Untuk simbol dan tanda baca tidak diisyaratkan.

5. Aplikasi ini tidak membahas kata yang termasuk kata semantik.

Metode yang dilakukan dalam pengembangan sistem ini yaitu metode waterfall (siklus air terjun). Tahapan dalam metode waterfall adalah (Pressman, 2002):

1. Rekayasa dan Pemodelan Sistem / Informasi

2. Analisis Kebutuhan Perangkat Lunak

3. Desain (Design)

4. Pemrograman (Coding)

5. Pengujian (Testing)

6. Pemeliharaan (Maintenance) pengujian.

Dalam penelitian ini yang dilakukan hanya sampai pada tahap kelima yaitu tahap

\section{LANDASAN TEORI}

Aplikasi Web

Aplikasi atau perangkat lunak adalah suatu subkelas perangkat lunak komputer yang memanfaatkan kemampuan komputer langsung untuk melakukan suatu tugas yang diinginkan. Aplikasi web itu sendiri dapat dibagi menjadi 2 yaitu: Web statis dan Web dinamis. Web statis dibentuk dengan menggunakan HTML saja, kekurangan aplikasi ini terletak pada keharusan untuk memelihara program secara terus-menerus untuk mengikuti setiap perubahan yang terjadi. Kelemahan ini diatasi dengan model apliksi Web dinamis (Kadir, 2003).

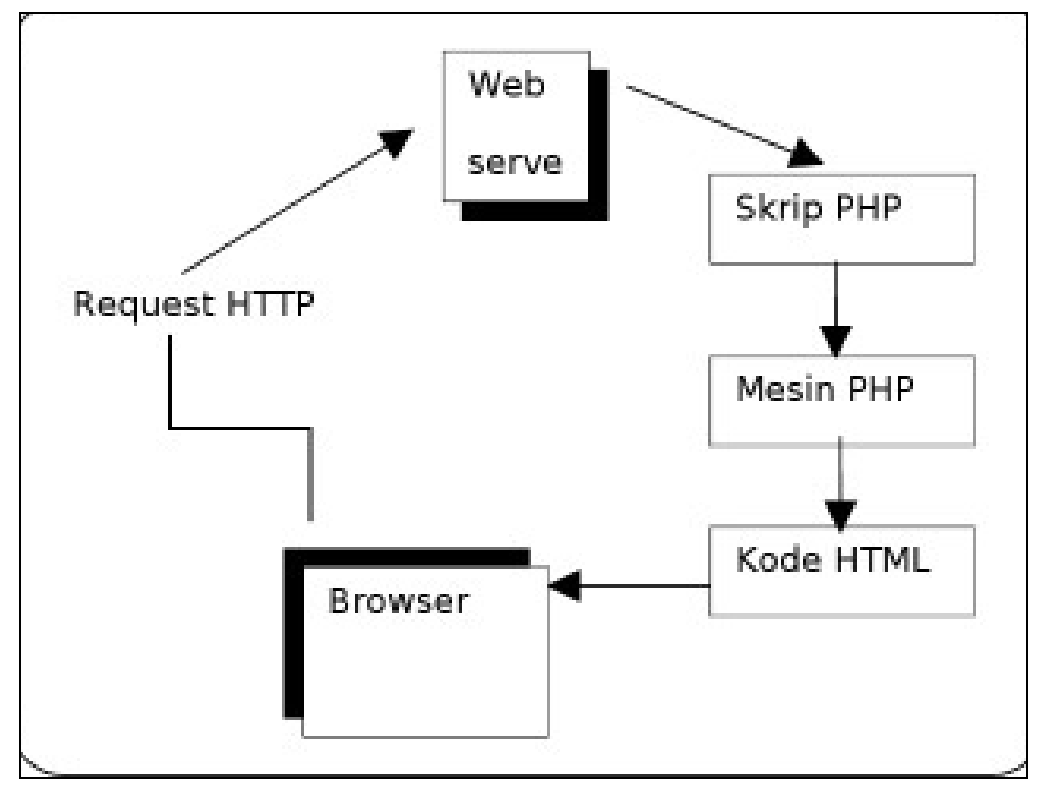

Tunarungu dan Bahasa Isyarat

Gambar 1. Alur Aplikasi web

Tunarungu dapat diartikan sebagai suatu keadaan kehilangan pendengaran yang mengakibatkan sseorang tidak dapat menangkap berbagai perangsang terutama melalui indera pendengaran (Dwidjosumarto, 1995). 
Perkembangan Pendidikan Anak Tunarungu

Menurut sejarah, pendidikan anak tunarungu dimulai setelah adanya perkembangan pandangan dan pengalaman terhadap kemampuan-kemampuan anak tunarungu. Kemampuan tersebut meliputi berbagai bidang, antara lain : mampu dilatih mengeluarkan suara / berbicara walaupun tidak dapat mendengar suara orang lain maupun suaranya sendiri, serta mampu berkomunikasi dengan masyarakat umumnya walaupun hanya menggunakan isyarat dan kadang-kadang disertai suara (Dwidjosumarto, 1995).

\section{Sistem Isyarat Bahasa Indonesia}

Sistem Isyarat Bahasa Indonesia (SIBI) yang dibakukan ini merupakan salah satu media yang membantu berkomunikasi sesama kaum tuna rungu dan dengan masyarakat luas. Wujudnya adalah tataan yang sistematis tentang seperangkat isyarat jari, tangan, dan berbagai gerak yang mlambangkan kosa kata bahasa Indonesia.

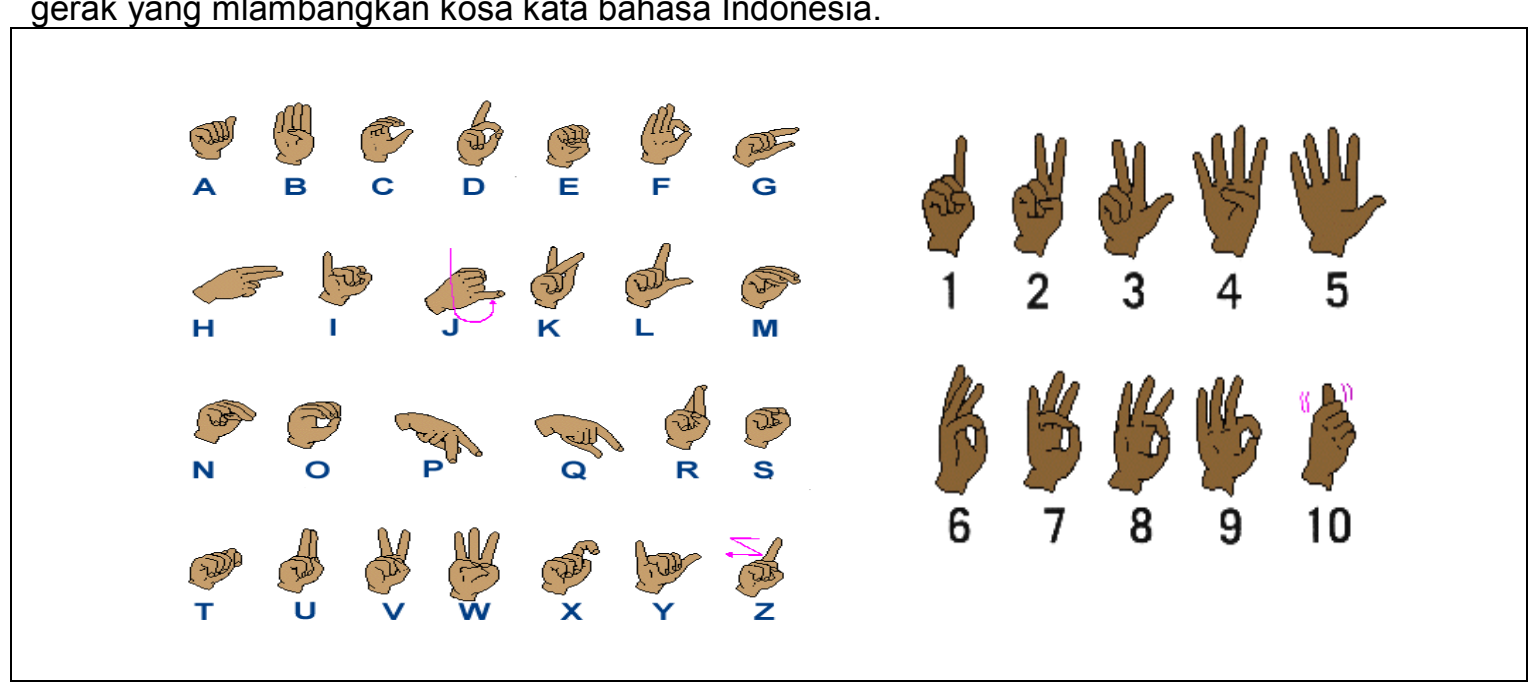

Gambar 2. Isyarat jari

Lingkup Sistem Isyarat Bahasa Indonesia

Berdasarkan pembentukannya, isyarat dapat dibedakan mnjadi 3 macam yaitu :

1. Isyarat Pokok

Isyarat Pokok ialah isyarat yang melambangkan sebuah kata / konsep. Isyarat ini dibentuk dengan berbagai macam penampil, tempat, arah, dan frekuensi.

2. Isyarat Tambahan

Isyarat Tambahan ialah isyarat yang melambangkan awalan, akhiran, dan partikel.

3. Isyarat Bentukan

Isyarat Bentukan ialah isyarat yang dibentuk dengan menggabungkan isyarat pokok dengan isyarat imbuhan dan dengan menggabungkan 2 isyarat pokok / lebih. (Dwidjosumarto, 1995).

\section{Penggunaan Bahasa Isyarat di sekolah}

Di sekolah Luar Biasa (SLB B-C) Yapenas Yogyakarta, penggunaan bahasa isyarat terbatas untuk siswa tunarungu saja. Bahasa isyarat ini digunakan oleh guru-guru untuk berkomunikasi dengan tunarungu, baik pada saat kegiatan belajar maupun di luar kelas. Hampir semua guru dapat berinteraksi dan berkomunikasi dengan siswa tunarungu dengan menggunakan acuan dari SIBI (Sistem Isyarat Bahasa Indonesia). Tetapi masih manual dalam penerapannya, yaitu membaca buku. Dalam segi efektifitas dirasa kurang jika kata yang dicari lebih dari satu atau banyak.

\section{ANALISIS DAN PERANCANGAN}

\section{Analisis Sistem}

Saat ini Sistem Isyarat Bahasa Indonesia (SIBI) masih digunakan untuk metode pendidikan yaitu sebagai alat bantu belajar mengajar dalam pendekatan isyarat alamiah, abjad jari dan isyarat yang dibakukan, akan tetapi untuk penggunaannya masih manual, sehingga sangat tidak efektif saat proses belajar mengajar berlangsung karena siswa maupun guru masih mencari kata-kata dalam kamus secara manual (membaca buku). 
Mungkin tidak terlalu berpengaruh apabila kata yang dicari satu atau dua saja, tetapi apabila kata yang dicari banyak, jelas akan membutuhkan waktu yang tidak sedikit. Oleh karena itu, perlu adanya suatu kamus elektronis khusus bahasa isyarat sebagai alat bantu tunarungu dalam bahasa Indonesia. Kamus tersebut berisi tataan yang sistematis tentang seperangkat jari, tangan, dan berbagai gerak yang melambangkan kosa kata bahasa Indonesia, sehingga mempermudah dalam belajar bahasa isyarat.

Analisis Kebutuhan Sistem

Berdasarkan permasalahan di atas, maka diperlukan spesifikasi kebutuhan untuk perancangan sistem yang akan dibangun. Spesifikasi kebutuhan ini terbagi menjadi tiga bagian, yaitu :

a. Kebutuhan masukan dari aplikasi kamus elektronik sebagai alat bantu isyarat bagi tunarungu dalam bahasa Indonesia yaitu pengguna (pengakses aplikasi) menginputkan kata dalam pencarian kata maupun pembuatan kalimat berupa text ke dalam aplikasi. Di sisi lain, admin dapat menambah data video.

b. Proses yang dilakukan dalam aplikasi ini adalah sistem akan membaca kata yang dimasukkan apakah sudah ada di dalam database. Kemudian jika data sudah ada, berdasarkan kata tersebut sistem akan menampilkan video peragaan isyarat.

c. Output yang diberikan oleh aplikasi ini adalah tampilan video peragaan isyarat sesuai dengan kata masukan.

\section{Perancangan Sistem}

DFD berikut menggambarkan aktifitas aliran data yang masuk atau keluar dari system yang berasal dan keluar menuju dua entitas system yaitu admin dan user umum. DFD level 1 terdiri dari proses menerjemahkan kata, menerjemahkan huruf dan angka, menerjemahkan kalimat, dan pengolahan bantuan dimana keempat proses diatas adalah proses yang dapat diakses oleh user umum. Sedangkan admin dapat melakukan pengolahan data kata-kata dalam kamus setelah melakukan login terhadap system

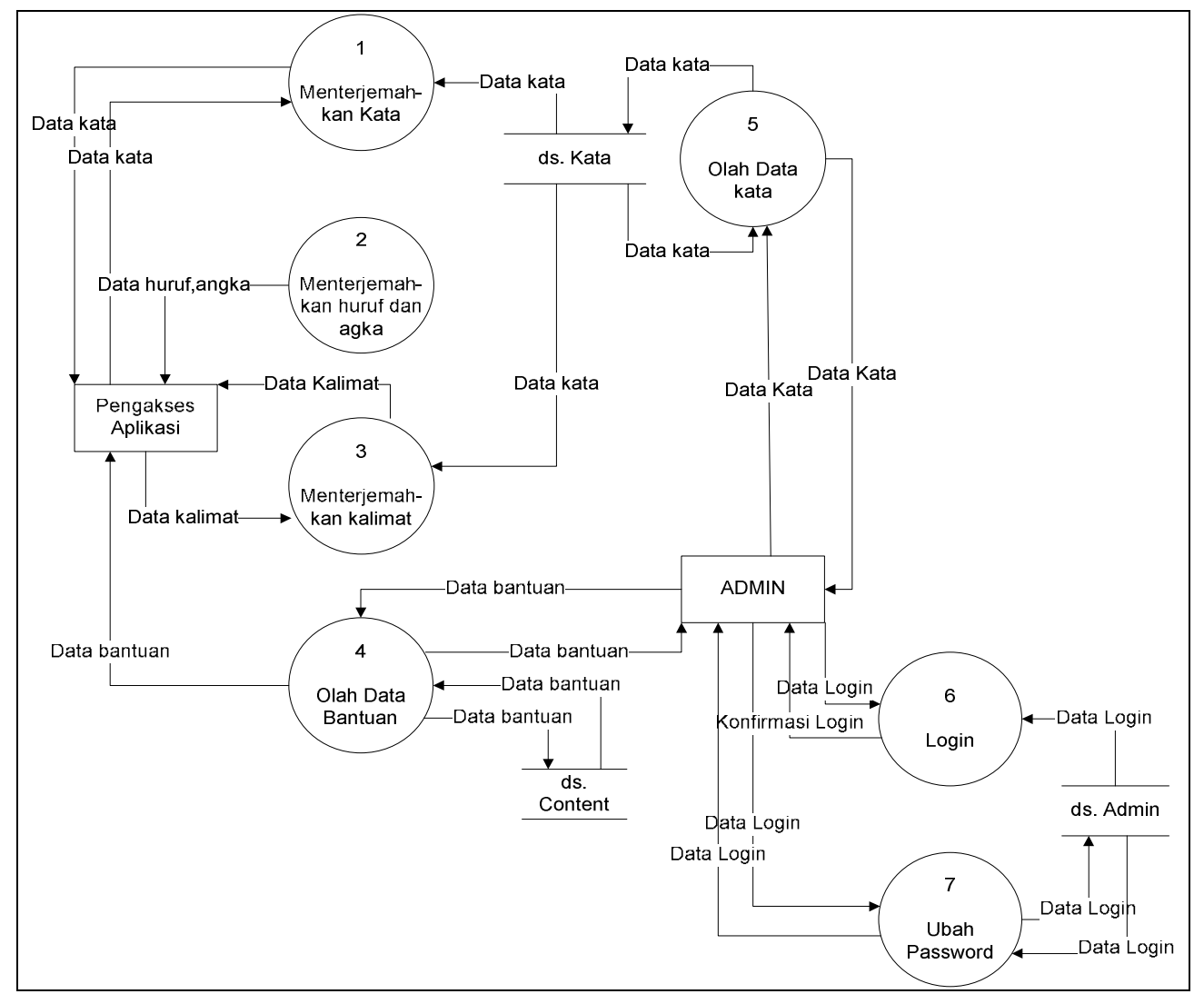

Gambar 3. DFD level 1 
Pada proses penerjemahan kalimat proses yang berjalan diterangkan lebih lanjut seperti dalam flowchart pada gambar 4 .

Data kamus disimpan dalam basis data, sehingga dapat terjadi kelengkapan terhadap konten kamus atau kamus memiliki lebih banyak lagi kosakatanya.

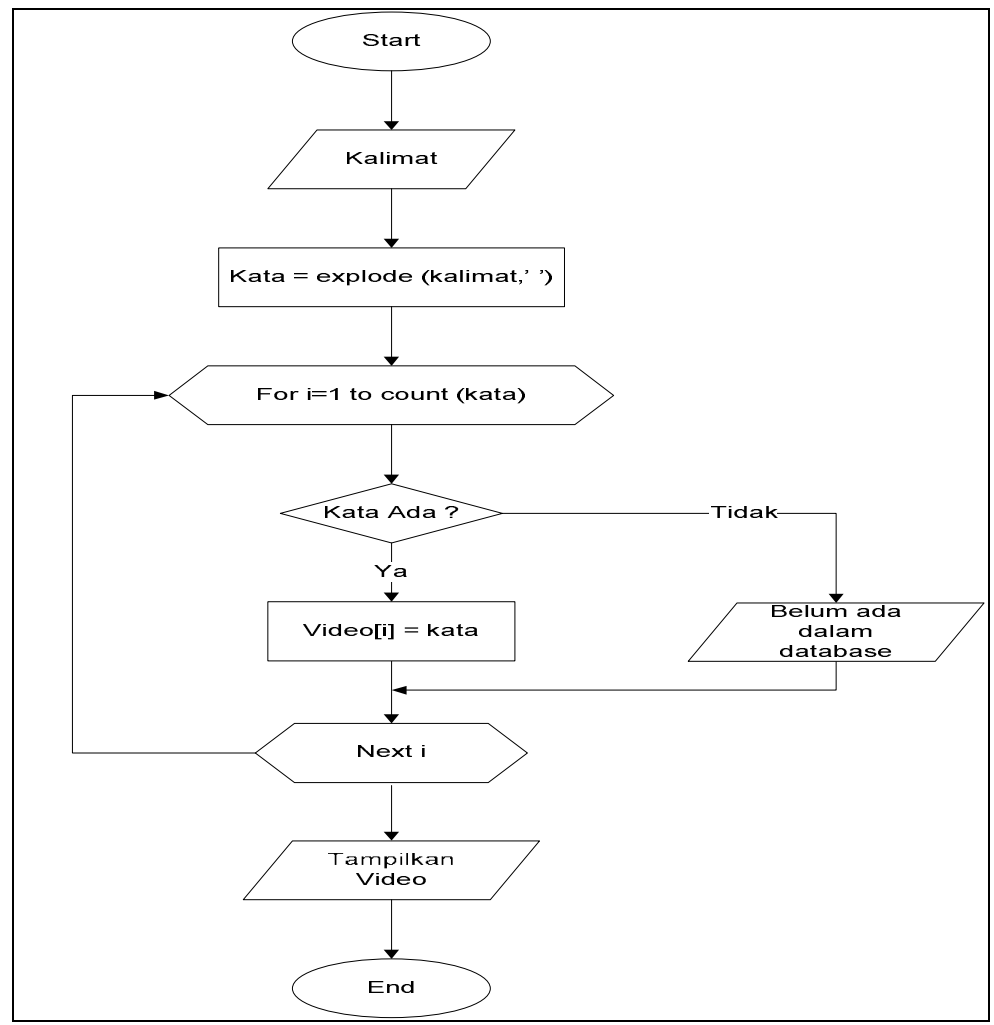

Gambar 4. Flowchart penerjemahan Kalimat

\section{PEMBAHASAN}

Aplikasi kamus elektronik memiliki output berupa gambar untuk penerjemahan huruf dan angka, ditampilkan pada gambar 5 , sedangkan untuk penerjemahan kata dan kalimat menggunakan video sebagai objek informasinya disajikan pada pada gambar 6 .

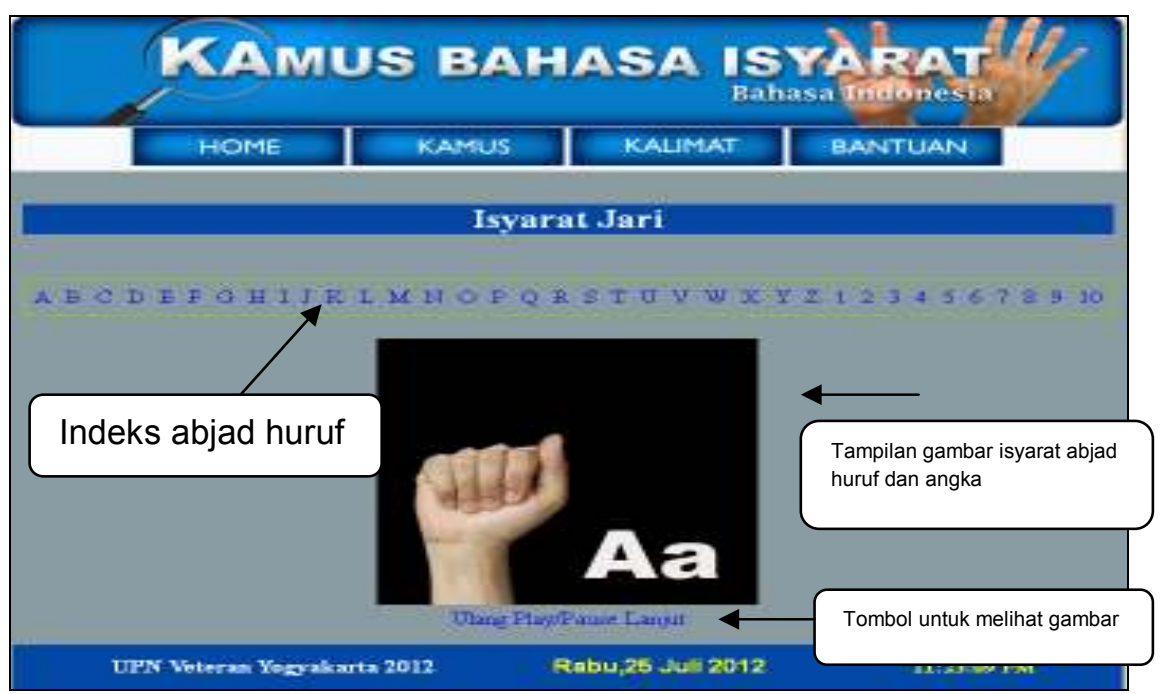

Gambar 5. Tampilan isyarat abjad huruf dan angka 
Pada penggunaan kamus isyarat berupa penerjemahan kalimat terlebih dahulu user memasukkan kalimat yang ingin diterjemahkan, kamudian proses penerjemahan dilakukan berdasarkan urutan kata pada kalimat yang dimaksud.

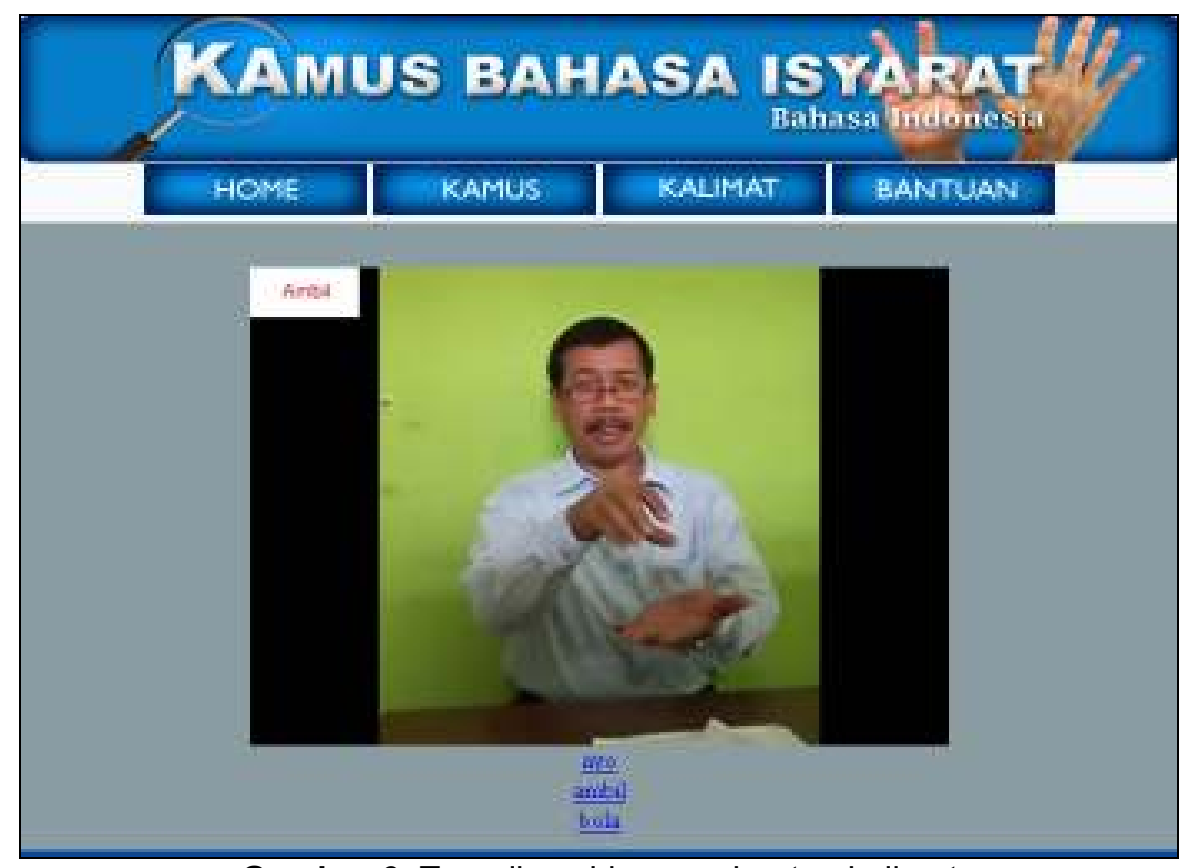

Gambar 6. Tampilan video pembuatan kalimat

\section{PENUTUP} bahwa :

Berdasarkan analisis, perancangan dan implementasi program, maka dapat disimpulkan

1. Telah berhasil dibangun sebuah aplikasi kamus elektronik sebagai alat bantu isyarat bagi tunarungu dalam bahasa Indonesia.

2. Aplikasi ini dapat digunakan sebagai media informasi maupun pembelajaran bahasa isyarat bagi guru, siswa berkebutuhan khusus (tunarungu), dan juga masyarakat umum secara online dan up to date melalui internet.

3. Aplikasi memiliki kelemahan dimana perlu adanya penambahan penggunaan kata atau kalimat yang berbentuk semantik.

\section{DAFTAR PUSTAKA}

Dwidjosumarto, A, 1995, Ortopedagogik Anak Tunarungu, Departemen Pendidikan dan Kebudayaan, Bandung.

Kadir, Abdul, 2003, Pengenalan Sistem Informasi, Penerbit Andi, Yogyakarta.

Wikipedia Indonesia, 2011, Bahasa Isyarat, http://id.wikipedia.org/wiki/Bahasalsyarat (diakses 10 April 2011)

2001, Kamus Sistem Isyarat Bahasa Indonesia, Departemen Pendidikan Nasional, Jakarta. 